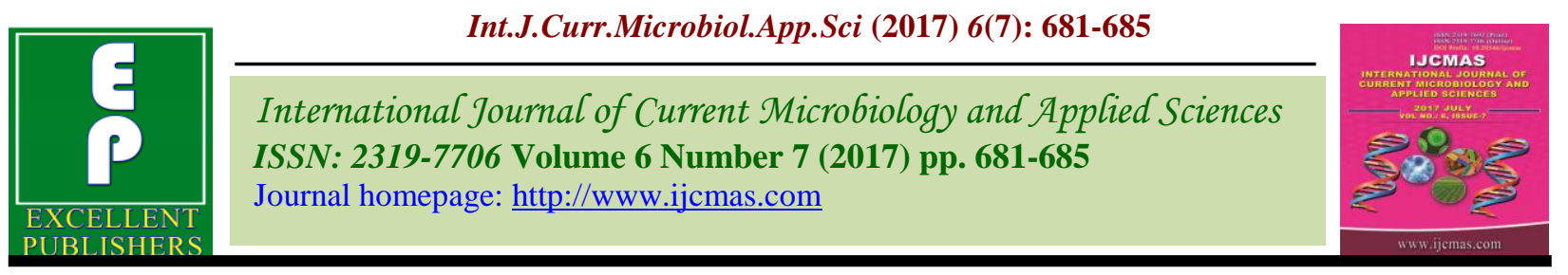

Original Research Article https://doi.org/10.20546/ijcmas.2017.607.083

\title{
Evaluation of Different Insecticides against Pod Borer (Helicoverpa armigera) in Lentil
}

\author{
S.A. Hakeem ${ }^{*}$, R.A. Wani ${ }^{1}$, Jahangeer A. Baba ${ }^{1}$, B.A. Allie ${ }^{1}$, N.A. Dar ${ }^{1}$, Sabiya Bashir ${ }^{1}$, \\ Seerat un Nissa ${ }^{1}$, Gul Zaffer ${ }^{1}$, S.A. Dar ${ }^{1}$ and B. Abrar Yaseen ${ }^{2}$ \\ ${ }^{1}$ Dryland Agricultural Research Station, Budgam, Sher-e- Kashmir University of Agricultural \\ Sciences and Technology, Kashmir, Jammu and Kashmir, India \\ ${ }^{2}$ Division of Entomology, Sher-e- Kashmir University of Agricultural Sciences and Technology, \\ Kashmir, Jammu and Kashmir, India \\ *Corresponding author
}

\section{A B S T R A C T}

\begin{tabular}{l} 
Ke y w o r d s \\
Lentil, \\
Pod borer, \\
Insecticide, \\
Pod damage, \\
Seed yield. \\
\hline Article Info \\
$\begin{array}{l}\text { Accepted: } \\
\text { 14 June } 2017 \\
\text { Available Online: } \\
\text { 10 July } 2017\end{array}$ \\
\hline
\end{tabular}

Keywords

Lentil, Pod damage, Seed yield.

rticle Info

Available Online

July 2017

\section{Introduction}

Lentil (Lens culinaris Medik), locally known as Masoor is an important Rabi season pulse crop. It is an Important Rabi season pulse crop. It is mainly cultivated in South Asia, West Asia, North Africa, The Nile region, North America, South America and Eastern Europe. Lentiles. India is a major producer of lentil crop in the world with $30 \%$ production of the total yield during 2001-2003, followed by Turkey and Canada with $18 \%$ and $16 \%$ respectively. In Pakistan it is cultivated as bosi crop after floods in Kacha area (both sides of the river Indus) or as a dubari crop after rice. Its seeds mostly eaten as dal (split seed). Bahl et al., reported that Lentil is probably the oldest of grain Legumes to be domesticated. The crop has primary product which is the seed with a relatively higher content of protein, carbohydrate and a calorie compared to other Legumes and is the most desired crop because of its high average protein content and fast cooking characteristics in many lentil producing regions. Under food Legumes, Lentil is 
affected by many biotic and abiotic factors. Among the biotic factors, insect pests play a significant role for reducing the yield per acre. Some of these are commonly important. Pod borer (Helicoverpa armigera) is a highly polyphagous and also a serious insect pest of Lentil crop. Pod borer, Helicoverpa armigera and Heliothis spp infest many host plants, especially lentil in west Asia and the subcontinent. Similarly, Van Emdren et al., have also reported that Heliothis armigera is an important pest of lentil crop. Patanker et al., have also reported that Helicoverpa armigera is the most serious pest of chickpea and other crop plants all over the world. In severe cases it causes about $75-90 \%$ losses in seed yield, he pointed out that gram pod borer damaged leaves tender shoots, apical tips, floral buds and pods.

Keeping in view the importance of the subject, an experiment was conducted to evaluate the response of insecticides against lentil pod borer.

\section{Materials and Methods}

An experiment was conducted to test the comparative efficacy of four different insecticides (Table 1) for management of pod borer (Helicoverpa armigera) on Lentil crop during rabi season 2016-2017 at DARS, Budgam. The experiment was laid out in randomized complete block design with three replications using five treatments including check. A lentil variety Shalimar Masoor-1 was planted on 20 0ct 2016 with row to distance of $0.15 \mathrm{~m}$. The plot size was $4.5 \mathrm{~m}^{2}$ $(1.5 \mathrm{mx} 3.0 \mathrm{~m})$. The first spray was applied with hand sprayer at pod formation stage to each treatment and the second treatment spray was applied after 15 days of intervals. Five plants were randomly selected from each treatment and observations were recorded 24 hours before spray and after 24 hours, 3 and 7 days of each spray. The reduction percentage of larvae was recorded by counting total number of live larvae before and after spray and pod damage percentage was recorded by counting the total number of pods and number of pods damaged by the pest. The observation was calculated according to Hendrson and Tilton formula, in order to determine the efficacy of insecticides. The pod yield data was recorded at the time of harvest. The data obtained was analysed statistically and means were compared by using Duncans Multiple Range Test

\section{Results and Discussions}

Data collected on the comparative efficacy of four different insecticides tested for management of pod borer in lentil crop was highly significant and is presented in table 24 , whereas the yield data is presented in table 5 .

Table.1 Insecticides and their doses used in the experiment

\begin{tabular}{|l|l|l|l|l|l|}
\hline S.No & \multicolumn{5}{|c|}{ Insecticides used } \\
\hline & Common name & local name & Group & Formulation & Dosage ml/ha \\
\hline 1 & Dimethoate & Rogar & organophosphate & 30 EC & 2500 \\
\hline 2 & Chloropyriphos & Dursiban & organophosphate & 20 EC & 2500 \\
\hline 3 & Profenophos & Curacron & organophosphate & 250 EC & 2500 \\
\hline 4 & Spinosad & Tracer & Naturalyte & 240 SC & 200 \\
\hline 5 & $\begin{array}{l}\text { Check (No } \\
\text { spray) }\end{array}$ & & & & \\
\hline
\end{tabular}


Table.2 Average larval population of pod borer (Helicoverpa armigera) on lentil crop before and after first spray of insecticides

\begin{tabular}{|l|l|l|l|l|l|l|}
\hline \multirow{2}{*}{ Insecticides over check } & \multicolumn{5}{|c|}{ Larval population/plant } \\
\cline { 2 - 7 } & $\begin{array}{l}\text { Before } \\
\text { spray }\end{array}$ & \multicolumn{5}{|c|}{ After spray } \\
\cline { 2 - 7 } & 24 hours & 24 hours & 3 days & 7 days & Mean & Percentage \\
\hline Rogar(Dimethoate) & 3.80 & 1.27 & 1.93 & 2.67 & 1.96 & 52.88 \\
\hline Dursiban(Chloropyriphos) & 3.67 & 1.07 & 2.13 & 2.47 & 1.89 & 54.57 \\
\hline Curacron(Profenophos) & 3.87 & 1.13 & 2.33 & 2.67 & 2.04 & 50.96 \\
\hline Tracer (Spinosad) & 3.93 & 0.87 & 1.80 & 2.13 & 1.60 & 61.54 \\
\hline Check (No spray) & 3.73 & 4.07 & 4.13 & 4.27 & 4.16 & \\
\hline
\end{tabular}

Table.3 Average larval population of pod borer (Helicoverpa armigera) on lentil crop before and after second spray of insecticides

\begin{tabular}{|l|l|l|l|l|l|l|}
\hline \multirow{2}{*}{$\begin{array}{c}\text { Insecticides over } \\
\text { check }\end{array}$} & \multicolumn{6}{|c|}{ Larval population/plant } \\
\cline { 2 - 7 } & $\begin{array}{l}\text { Before } \\
\text { spray }\end{array}$ & \multicolumn{5}{c|}{ After spray } \\
\cline { 2 - 7 } & 24 hours & 24 hours & 3 days & 7 days & Mean & Percentage \\
\hline Rogar & 3.93 & 1.07 & 1.60 & 2.47 & 1.71 & 58.80 \\
\hline Chloropyriphos & 3.73 & 1.00 & 1.33 & 2.40 & 1.58 & 61.93 \\
\hline Profenophos & 4.07 & 1.20 & 1.87 & 2.60 & 1.89 & 54.46 \\
\hline Spinosad & 3.87 & 0.73 & 1.27 & 1.93 & 1.31 & 68.43 \\
\hline Check (No spray) & 4.13 & 4.27 & 4.00 & 4.20 & 4.15 & \\
\hline
\end{tabular}

Table.4 Average reduction percentage of pod damage of different intervals on lentil crop, sprayed with different insecticides

\begin{tabular}{|l|l|l|l|l|l|l|}
\hline \multirow{2}{*}{ Insecticide } & \multicolumn{2}{|l|}{ During first spray } & \multicolumn{2}{|c|}{ During second spray } & Mean of & Both sprays \\
\cline { 2 - 7 } & Mean & $\begin{array}{l}\text { \% age } \\
\text { over } \\
\text { check }\end{array}$ & Mean & $\begin{array}{l}\text { Reduction\%age } \\
\text { over check }\end{array}$ & Mean & $\begin{array}{l}\text { Reduction } \\
\text { \%age over } \\
\text { check }\end{array}$ \\
\hline Rogar & 2.4 & 80.2 & 2.8 & 78.6 & 2.6 & 79.4 \\
\hline Dursiban & 2.7 & 78.0 & 2.3 & 82.4 & 2.5 & 80.2 \\
\hline Curacron & 2.5 & 79.3 & 4.2 & 67.9 & 3.4 & 73.6 \\
\hline Tracer & 2.1 & 82.6 & 1.9 & 85.5 & 2.0 & 84.1 \\
\hline $\begin{array}{l}\text { Check } \\
\text { (No spray) }\end{array}$ & 12.1 & & 13.1 & & 12.6 & \\
\hline
\end{tabular}


Table.5 Seed yield data of lentil crop

\begin{tabular}{|l|l|l|l|}
\hline \multirow{2}{*}{ Insecticide over check } & \multicolumn{2}{|c|}{ Yield } & \multirow{2}{*}{$\%$ increased } \\
\cline { 2 - 3 } & Mean (kg/plot) & Mean (kg/ha) & \\
\hline Rogar (Dimethoate) & $3.37 \mathrm{~d}$ & 748.20 & +30.7 \\
\hline Dursiban(Chloropyriphos) & $3.98 \mathrm{~b}$ & 885.20 & +41.4 \\
\hline Curacron(Profenophos) & $3.55 \mathrm{c}$ & 788.90 & +34.3 \\
\hline Tracer (Spinosad) & $4.63 \mathrm{a}$ & 1029.6 & +49.6 \\
\hline Check (No spray) & $2.33 \mathrm{e}$ & 518.5 & \\
\hline
\end{tabular}

\section{Reduction percentage of larval population}

First spray: The results presented in Table 2 revealed that the tracer (Spinosad) is the most effective insecticide among all the insecticides tested at 24 hours, 3 and 7 days after application of first spray in controlling the pod borer on lentil crop, followed by Chlorpyriphos and Dimethoate. Curacron (Profenophos) was found to be the least effective. The reduction percentage of larvae population over check was high recorded with tracer (61.54), followed by Chloropyriphos (54.57) and Rogar (52.88), whereas profenophos (50.96) resulted the minimum reduction percentage over check.

\section{Second spray}

The results of second spray (Table 3) showed that the tracer (Spinosad) was also more effective in respect of reducing the larval population of pod borer when compared with insecticides tested at 24 hours, 3 and 7 days followed by Chloropyriphos, Rogar and profenphos. The reduction percent of larval population over check was also high recorded with Tracer (68.43), followed by Chloropyriphos (61.93), Rogar (58.80) and Profenphos (54.46).

\section{Reduction percentage of pod damage}

The results of reduction percentage of pod damage are presented (Table 4) showed that the application of spinosad was more effective in damage reduction percentage of pods with $82.6 \%$ followed by Dimethoate (80.2\%), Profenphos (79.3\%) and Chloropyriphos $(78.0 \%)$ during the first spray. Similarly, during the second spray of insecticide, Tracer also remained the top most effective and showed the maximum pod damage reduction percentage with $85.5 \%$, whereas the minimum reduction percentage of pod damage was achieved (67.9\%) with profenphos. At the average results of both sprays (Table 4) revealed that application of Spinosad resulted in the maximum reduction percentage of Pod damage was $84.2 \%$, followed by Chloropyriphos $80.2 \%$, Dimethoate $79.4 \%$ whereas the profenphos resulted in the minimum reduction percentage of pod damage with $73.6 \%$.

\section{References}

Anonymous. 2004. The Global pulse markets: recent trends and outlook. CICILS/IPTIC 2004 Convention, 10-12 june Beijing China, p. 1-30.

Attique, M.R., M.I. Arif, Z. Ahmed and M.I. Mohyddin. 2000. Host plants and population dynamics of Helicoverpa armigera (Hubner) in the belt of Punjab. The Pak. Cottons, 44(3\&4): 3140.

Babariya, P.M., B.B. Kabaria, V.N. Patel and M.D. Joshi. 2010. Chemical control of gram pod borer (Helicoverpa armigera) infesting pigeon pea. Legume Res., 33(3). 
Bahl, P.N., S. Lal and B.M. Sharma. 1993.An overview of the production and problems in the southeast Asia, p. 1-10. In: W. Erskine and M.C. Saxena (eds.) Lentil in South Asia. Proceedings of the seminar on Lentils in south Asia. ICARDA, Aleppo, Syria.

Cubero, J.I. 1981. Origin, taxonomy and domestication p.15-38. In: C. Webb and G. Hawtin (eds), Lentils, C.A.B: London, UK.

Duke, J.A. 1981. Handbook of Legumes of wor4ld economic importance. Plenum Press, New York, p 52-57.

Kambreker, D.N. 2013. Management of pod borer in pigeon pea. Sci. Tech.

Ladizinsky, G. 1979. The origin of Lentil and wild gene pool, Euphytica, 28: 179-187.

Lal, O.P. 1996. An outbreak of pod borer on Chickpea in eastern Uttar Pradesh (India). J. Entomol. Res., 20: 179-181.

Muchlbaur, F.J., Cubero and R.J. Summerfield. 1985. Lentil (Lens culinaris Medic) p. 266-311. In: R.J. Summerfield and E.H. Roberts (eds), Grain Legume Crops, Collins, 8 Grafton street, London, UK.

Patanker, A.G., A.P. Giri, A.M. Harsulkar, M.N. Sainari, V.V. Deshpade, P.K.
Ranjekar and V.S. Gupta. 2001. Complexity in specificities and expression of Helicoverpa armigera gut proteinases explains polyphagous nature of insect pest. Insect Biochem. Mol. Bio., 31: 453-464.

Ruberson, J.R., and P.G. Tillman. 1999. Effect of selected insecticides in natural enemies in cotton, Laboratory studies. Proceedings Beltwide Cotton Conferences, pp. 1210-1213.

Salgado, V.L., G.B. Watson and J.J. Sheets. 1997. Studies on the mode of action of Spinosad, the active ingredient in Tracer insect control. Proceedings Beltwide cotton conference, pp. 1082-1086.

Sreekanth, M. and M. Seshamahalakashmi. 2010. Studies on relative toxicity of bio pesticides to Helicoverpa armigera and Maruca vitdate on pigeon pea. $J$. Biopesticides, 52: 191-195.

Thompson, G.D., P.W. Borth, M.C. Shaw, R.W. Huckaba, B.A. Nead, L.G. Peterson, J.M. Richardson, and D.J. Porteous. 1996a. Spinosad and the new naturalyte insect control class. Proceedings Beltwide cotton conferences, pp. 870-872.

\section{How to cite this article:}

Hakeem, S.A., R.A. Wani, Jahangeer A. Baba, B.A. Allie, N.A. Dar, Sabiya Bashir, Seerat un Nissa, Gul Zaffer, S.A. Dar and Abrar Yaseen, B. 2017. Evaluation of Different Insecticides against Pod Borer (Helicoverpa armigera) in Lentil. Int.J.Curr.Microbiol.App.Sci. 6(7): 681685. doi: https://doi.org/10.20546/ijcmas.2017.607.083 